\title{
PELATIHAN PENULISAN ARTIKEL ILMIAH BERBASIS RISET BAGI GURU DAN TEKNIK SUBMISSION DI JURNAL NASIONAL
}

\author{
Mutia Fonna ${ }^{1)}$, Mursalin ${ }^{1)}$, Aklimawati ${ }^{1)}$, Muliana ${ }^{1)}$, Fajriana ${ }^{1)}$, Henni Fitriani ${ }^{2}$, Ayu Rahmi ${ }^{22}$, \\ Ratna Unaida ${ }^{3)}$, Fakhrah ${ }^{3)}$, Nanda Novita ${ }^{4)}$, Syarifah Rita Zahara ${ }^{4)}$, Halimatus Sakdiah ${ }^{4)}$ \\ 1)Prodi Pendidikan Matematika, Fakultas Teknik, Universitas Malikussaleh, Lhokseumawe, Aceh, Indonesia \\ 2)Prodi Pendidikan Kimia, Fakultas Teknik, Universitas Malikussaleh, Lhokseumawe, Aceh, Indonesia \\ 3)Prodi Pendidikan Bahasa Indonesia, Fakultas Teknik, Universitas Malikussaleh, Lhokseumawe, Aceh, Indonesia \\ 4)Prodi Pendidikan Fisika, Fakultas Teknik, Universitas Malikussaleh, Lhokseumawe, Aceh, Indonesia \\ Corresponding author : Mutia Fonna \\ E-mail : mutia.fonna@unimal.ac.id
}

Diterima 14 Oktober 2021, Direvisi 24 Oktober 2021, Disetujui 25 Oktober 2021

\begin{abstract}
ABSTRAK
Kegiatan pengabdian ini dilaksanakan di SMP Negeri 1 Dewantara, Aceh utara. Tujuan pengabdian ini untuk memberikan pengetahuan bagi guru-guru dalam menulis artikel ilmiah, mengembangkan pengetahuan dan meningkatkan kualitas penulisan artikel ilmiah, melatih guru untuk mempublikasikan artikel penelitian secara mandiri pada jurnal nasional berbasi OJS (Open Journal System). Kegiatan ini di dasari oleh permasalahan mitra yaitu: (1) Belum adanya pelatihan khusus untuk mendukung penulisan karya ilmiah berbasis riset. (2) Minimnya pengetahuan guru dan keterbatasan ide dalam penulisan karya ilmiah. (3) Guru masih mengalami kesulitan untuk mempublikasikan artikel ilmiah secara mandiri pada jurnal nasional. Metode pelaksanaan kegiatan terdiri dari 3 tahapan yaitu. Tahapan sosialisasi dan diskusi dilakukan melalui penyuluhan (pemaparan materi) tentang (1) Penulisan Artikel IImiah Berbasis Riset Bagi Guru dan Teknik Submission di Jurnal Nasional dan (2) Teknik Submission Artikel di Jurnal Nasional Berbasis OJS. Tahap kedua yaitu tahapan diskusi dimana pada tahap ini dilanjutkan dengan diskusi berupa tanya jawab antara pemateri dengan peserta. Tahap ketiga yaitu mempraktekkan bagaimana cara submit artikel ilmiah sesuai dengan target submission jurnal nasional berbasis OJS. Hasil yang diperoleh yaitu semua peserta antusias mengikuti kegiatan pelatihan yang diberikan, hal ini terlihat dari para peserta yang menyimak dengan seksama materi yang disampaikan, dan mengajukan pertanyaan ketika ada kendala yang belum dipahami.
\end{abstract}

Kata kunci: penulisan artikel Imiah; teknik submission

\begin{abstract}
This service activity was carried out at SMP Negeri 1 Dewantara, North Aceh. The purpose of this service is to provide knowledge for teachers in writing scientific articles, develop knowledge and improve the quality of writing scientific articles, train teachers to publish research articles independently in national journals based on OJS (Open Journal System). This activity is based on partner problems, namely: (1) There is no special training to support the writing of research-based scientific papers. (2) The lack of teacher knowledge and limited ideas in writing scientific papers. (3) Teachers still have difficulty publishing scientific articles independently in national journals. The method of implementing the activity consists of 3 stages, namely. The stages of socialization and discussion are carried out through counseling (exposure to material) on (1) Research-Based Scientific Article Writing for Teachers and Submission Techniques in National Journals and (2) Article Submission Techniques in OJS-Based National Journals. The second stage is the discussion stage where at this stage it is followed by a discussion in the form of questions and answers between the presenter and the participants. The third stage is to practice how to submit scientific articles in accordance with the OJS-based national journal submission target. The results obtained are that all participants are enthusiastic about participating in the training activities provided, this can be seen from the participants who listen carefully to the material presented, and ask questions when there are obstacles that are not yet understood.
\end{abstract}

Keywords: scientific article writing; submission techniques

PENDAHULUAN
Diberlakukannya UU No.20 tahun 2003
tentang sistem pendidikan nasional
mengisyaratkan adanya pendidikan yang

bermutu. Dengan diberlakukannya UU ini, diharapkan guru akan lebih mampu bekerja sebagai tenaga profesional dalam melaksanakan tugas dan tanggung jawabnya. 
Kebijakan pemerintah yang tertuang dalam UU tersebut juga berkaitan dengan promosi kenaikan pangkat/jabatan guru berdasarkan prestasi kerja. Prestasi kerja yang dimaksud harus sesuai dengan tugas pokok dan fungsinya, yang meliputi kegiatan: (1) pendidikan, (2) proses pembelajaran, (3) pengembangan profesi, dan (4) penunjang proses pembelajaran.

Keputusan Menteri Negara Pendayagunaan Aparatur Negara nomor 84/1993 tentang Jabatan Fungsional Guru dan Angka Kreditnya, serta Keputusan bersama Menteri Pendidikan dan kebudayaan dan Kepala BAKN Nomor 0433/P/1993, nomor 25 tahun 1993 tentang Petunjuk Pelaksanaan Jabatan Fungsional Guru dan Angka Kreditnya, pada prinsipnya bertujuan untuk membina karier kepangkatan dan profesionalisme guru. Kebijakan itu di antaranya mewajibkan guru untuk melakukan keempat kegiatan yang menjadi bidang tugasnya, dan hanya bagi mereka yang berhasil melakukan kegiatan dengan baik diberikan angka kredit. Selanjutnya angka kredit itu dipakai sebagai salah satu persyaratan peningkatan karir dan pengembangan profesi. Salah satu syarat yang harus dipenuhi dalam rangka peningkatan karir dan pengembangan profesi adalah menulis karya ilmiah. Guru atau pengajar dituntut untuk kreatif meneliti (dalam berbagai skala dan bentuk) dan menulis hasil penelitian maupun analisisnya dalam suatu artikel ilmiah. Setidaknya ada 2 fungsi yang dapat dipetik oleh seorang guru tatkala mereka menulis suatu artikel ilmiah dalam jurnal. Pertama, secara akademik guru dapat menularkan hasil penelitian dan analisisnya guna menyumbang kemajuan informasi, khususnya di bidang pendidikan. Kedua, secara profesional guru akan mendapatkan "kredit poin" yang dapat digunakan untuk meningkatkan karir dan profesionalisme kinerjanya.

Berdasarkan penelitian yang pernah dilakukan diketahui bahwa ada tiga faktor yang secara bersama - sama terhadap minat guru menulis artikel ilmiah yaitu faktor diri sendiri, sosial dan emosional berpengaruh signifikan (Sakdiah, 2021). Selain faktor tersebut dibutuhkan pula kemampuan literasi digital pada guru tidak hanya dalam pembelajaran tapi juga dalam penulisan artikel (Novita, Marhami, Sakdiah, \& Muliani, 2021).

Berdasarkan hasil observasi dan wawancara pada hari kamis, tanggal $21 \mathrm{Juli}$ 2021 dengan beberapa guru di SMPN 1 Dewantara, para guru saat ini memiliki kesulitan dalam menulis artikel ilmiah hasil penelitian yang memenuhi syarat publikasi pada sebuah jurnal nasional, sehingga karya intelektual yang dihasilkan guru dalam jurnal ilmiah masih sangat terbatas. Hal ini dipertegas oleh kepala sekolah SMPN 1 Dewantara bahwa ada beberapa golongan guru berdasarkan jenjang usia yang memiliki kendala dalam menaiikan pangkat disebabkan oleh minimnya pengetahuan dan kemampuan guru terkait dengan penulisan arttikel ilmiah. Lebih lanjut para guru belum mengetahui bagaimana cara mempublikasikan artikel secara mandiri pada jurnal yang sesuai dengan bidang kajian dan keilmuan.disamping itu kurangnya pemahaman guru tentang katagori jurnal baik jurnal nasional, jurnal nasional terakreditasi, jurnal internasional, dan jurnal internasional bereputasi. Karya tulis ilmiah memiliki peran strategis dalam upaya pengembangan profesi guru. Sebagaimana diketahui bahwa karya pengembangan profesi merupakan salah satu butir penting bagi guru dalam meraih kenaikan pangkat. Berdasarkan uraian di atas, dipertimbangkan perlu dilakukan kegiatan pelatihan penulisan karya ilmiah berbasis riset bagi guru dan Teknik submission di jurnalnasional. Harapannya, setelah pelaksanaan kegiatan pelatihan ini guru-guru menjadi lebih produktif dalam menghasilkan karya tulis ilmiah secara mandiri. Sedangkan untuk pengembangan keprofesian berkelanjutan, guru harus mampu melakukan publikasi ilmiah hasil penelitian atau gagasan dalam bidang ilmu pendidikan (Hamidsyukrie, Syafruddin, \& Muntari, 2020).

Tujuan dari kegiatan ini adalah: Memberikan pengetahuan bagi guru-guru yang belum berpengalaman dalam menulis artikel ilmiah, mengembangkan pengetahuan dan meningkatkan kualitas penulisan artikel ilmiah bagi guru. Melatih guru untuk mempublikasikan/ submit artikel penelitian pada jurnal nasional. Mendorong dan meningkatkan jumlah publikasi hasil penelitian guru sebagai salah satu syarat kenaikan pangkat.

\section{METODE}

Pelaksanan kegiatan Pengabdian Kepada Masyarakat (PKM) Pelatihan Penulisan Artikel IImiah Berbasis Riset Bagi Guru Dan Teknik Submission Di Jurnal Nasional ini dilaksanakan pada hari Kamis tanggal 05 Agustus 2021 SMPN 1 Dewantara dengan jumlah guru keseluruhan adalah 56 yang mengajar berbagai bidang mata pelajaran, tendik 16 orang dan total peserta didik 551 orang. Dari sejumlah guru yang mengajar di sekolah tersebut ada 20 pengajar yang mengikuti pelatihan ini.

Tahapan kegiatan program Pengabdian Kepada Masyarakat dapat dilihat berdasarkan tabel 1 berikut. 
Tabel 1. Tahapan Kegiatan Pengabdian Kepada Masyarakat

\section{Tahap Persiapan}

\begin{tabular}{|c|c|}
\hline Pra-Survei & $\begin{array}{l}\text { Identifikasi permasalahan dan } \\
\text { kebutuhan mitra (permasalahan } \\
\text { spesifik yang dialami mitra) }\end{array}$ \\
\hline $\begin{array}{l}\text { Pembentuka } \\
\text { n Tim PKM }\end{array}$ & $\begin{array}{l}\text { Pembentukan Tim disesuaikan } \\
\text { dengan jenis kepakaran untuk } \\
\text { Menyelesaikan permasalahan } \\
\text { mitra }\end{array}$ \\
\hline $\begin{array}{l}\text { Pembuata } \\
\text { n Proposal }\end{array}$ & 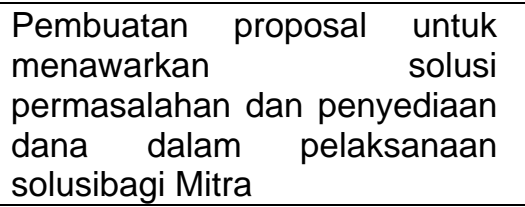 \\
\hline $\begin{array}{l}\text { Koordiasi } \\
\text { Tim dan } \\
\text { Mitra }\end{array}$ & $\begin{array}{l}\text { Perencanaan pelaksanaan } \\
\text { program secara konseptual, } \\
\text { Operasional dan jobdescribtion } \\
\text { dari Tim \& Mitra }\end{array}$ \\
\hline $\begin{array}{l}\text { Persiapan } \\
\text { Alat \& } \\
\text { Bahan }\end{array}$ & $\begin{array}{l}\text { Foto copy bahan dan Pembuatan } \\
\text { materi kegiatan }\end{array}$ \\
\hline
\end{tabular}

Bahan

\section{Tahap Pelaksanaan}

(Kegiatan Dilaksanakan diLokasi Mitra)

\begin{tabular}{|c|c|}
\hline $\begin{array}{l}\text { Sosialisasi } \\
\text { penulisan } \\
\text { artikel ilmiah } \\
\text { yang sesuai } \\
\text { dengan } \\
\text { kaidah } \\
\text { penulisan } \\
\text { artikel ilmiah }\end{array}$ & $\begin{array}{l}\text { Kegiatan dilaksanakan melalui } \\
\text { pemaparan materi dan diskusi } \\
(4 \mathrm{JP})\end{array}$ \\
\hline $\begin{array}{l}\text { Sosialisasi } \\
\text { cara } \\
\text { melakukan } \\
\text { submission } \\
\text { jurnal/ artikel } \\
\text { ilmiah }\end{array}$ & $\begin{array}{l}\text { Kegiatan dilaksanakan melalui } \\
\text { pemaparan materi dan praktik } \\
\text { langsung bagaimana } \\
\text { mengsubmission }(3 \mathrm{JP})\end{array}$ \\
\hline $\begin{array}{l}\text { Simulasi } \\
\text { submit artikel } \\
\text { ilmiah pada } \\
\text { jurnal } \\
\text { nasional }\end{array}$ & $\begin{array}{l}\text { Kegiatan dilaksanakan oleh } \\
\text { peserta pelatihan dengan } \\
\text { mengikuti arahan dari } \\
\text { permateri dan didampingi oleh } \\
\text { TIM PKM ( } 8 \mathrm{JP} \text { ) }\end{array}$ \\
\hline $\begin{array}{l}\text { Pendamping } \\
\text { an secara } \\
\text { online }\end{array}$ & $\begin{array}{l}\text { Setelah selesai kegiatan PKM } \\
\text { dilaksanakan secara langsung } \\
\text { di sekolah, pendampingan dan } \\
\text { bimbingan kepada peserta } \\
\text { dilanjutkan secara online (17 } \\
\text { JP) }\end{array}$ \\
\hline
\end{tabular}

Penyusunan laporan dilakukan sebagai bentuk pertanggungjawaban atas pelaksanaan program untuk kemudian dilakukan publikasi

\footnotetext{
Ada beberapa metode pendekatan yang digunakan dalam pelaksanaan program,meliputi:
}

1. Sosialisasi

Program pengabdian kepada masyarakat dilaksanakan dalam bentuk sosialisasi kepada mitra yaitu dewan guru SMP N 1 Dewantara. Sosialisasi tersebut berupa pemamparan materi kepada mitra terkait permasalahan yang dihadapi mitra yaitu kurangnya pemahaman para dewan guru dalam menulis artikel ilmiah dan bagaimana teknik mengsubmission artikel ilmiah. Materi yang akan disampaikan diharapkan dapat memberikan peningkatan pengetahuan dan pemahaman untuk selanjutnya dapat diterapkan oleh mitra dalam kegiatan menulis artikel ilmiah. Adapun materi yang disampaikan yaitu (1) Penulisan Artikel Ilmiah Berbasis Riset Bagi Guru Dan Teknik Submission di Jurnal Nasional dan (2) Teknik Submission Artikel Di Jurnal Nasional Berbasis OJS.

2. Diskusi

Setelah materi selesai dipaparkan, dilanjutkan dengan diskusi berupa tanya jawaban pemateri dengan peserta. Diskusi dilakukan agar peserta lebih memahami tentang materi yang telah disampaikan. Melalui diskusi, sosialisasi tidak hanya sekedar transfer knowledge saja melainkan dapat sharing pengalaman maupun permasalahan yang sedang dihadapi mitra.

3. Simulasi Submission Jurnal / Artikel IImiah Setelah kegiatan diskusi dilaksanakan selanjutnya kegiatan yang dilakukan adalah mempraktekkan bagaimana cara mengsubmission jurnal/artikel ilmiah sesuai dengan target submission jurnal internasional. Tujuaanya dilakukan kegiatan ini yaitu untuk mempermudah dewan guru dalam mengsubmisson jurnal dan memilih tujuan jurnal yang akan dterbitkan.

\section{HASIL DAN PEMBAHASAN \\ Analisi Hasil}

Analisis hasil ini diperoleh berdasarkan evaluasi-evaluasi dari tiap permasalahan yang ada di sekolah tempat dilakukannya kegiatan pengabdian. Sebelumnya diketahui bahwa permasalahan guru di sekolah terkait dengan penulisan artikel ilmiah ada dua permasalahan, diantaranya dewan guru masih kurang memahami bagaimana teknik menulis artikel ilmiah yang baik dan benar sesuai dengan kaidah penulisan ilmiah dan kurangnya pengetahuan dan pemahaman guru tentang cara mengsubmit jurnal/artikel ilmiah. Melalui kegiatan pengabdian ini, tim pengabdian berusaha memberikan solusi untuk mengatasi permasalahan tersebut, yaitu dengan memberikan sosialisasi penulisan artikel ilmiah 
yang sesuai dengan kaedah penulisan artikel ilmiah dan juga mengadakan workshop tentang teknik submission jurnal/artikel ilmiah.

\section{Sosialisasi Penulisan Artikel IImiah}

Sosialisasi penulisan artikel ilmiah bagi guru dianggap perlu dilakukan mengingat kewajiban guru untuk mengusulkan kenaikan pangkat salah satunya adalah menghasilkan karya ilmiah sebagai bukti pengembangan diri guna memenuhi angka kredit guru. Output dari sosialisasi di sesi pertama ini dapat dilihat dari gambar di bawah ini, dimana peserta menunjukkan perilaku yang sangat kondusif, artinya para peserta memberikan perhatian dan menyimak pemaparan materi yang disampaikan, perilaku lain yang ditunjukkan adalah peserta mengajukan pertanyaan disaat ada materi yang kurang jelas. Gambar 1 menunjukkan keadaan saaat pemberian materi sedang berlangsung.

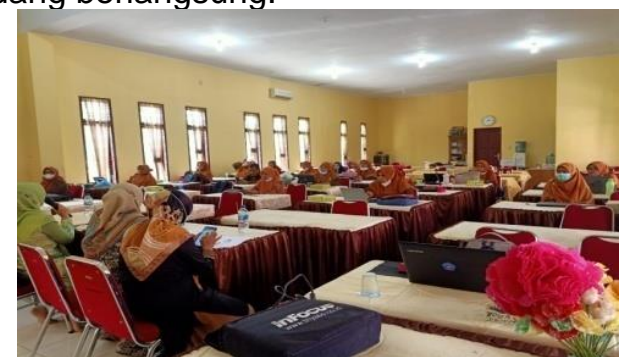

Gambar 1. Kondisi pada saat berlangsungnya kegiatan penyampaian materi pelatihan

(Sumber: Tim Pengabdian)

Semua peserta antusias mengikuti pelatihan yang diberikan, hal ini terlihat dari para peserta menyimak dengan seksama pemateri menjelaskan, dan peserta mau mengajukan pertanyaan disaat ada pemaparan materi yang belum dipahami oleh peserta.

Pertanyaan yang diajukan peserta umumnya adalah mengenai penyusunan naskah jurnal yang berasal dari PTK atau karya tulis lainnya. Setelah pemateri menjelaskan struktur artikel secara umum para peserta sudah mulai memahami point-point mana saja yang harus ditampilkan dalam naskah jurnal ilmiah.

Dari kegiatan sosialisasi ini peserta juga dapat mengetahui berbagai macam jenis jurnal dan juga cara untuk mendaftarkan karya tulis yang dihasilkan ke dalam jurnal nasional dengan dipaparkan secara jelas beberapa contoh website dan rumah Jurnal OJS (Open Journal System) sesuai dengan mata pelajaran para peserta pelatihan. Pemateri juga menyampaikan contoh pengindeks jurnal serta pangkalan databased jurnal terakreditasi (SINTA).

\section{Teknik Submission Jurnal}

Untuk mengatasi permasalahan para guru yang belum dapat mendaftarkan karya tulisnya ke dalam jurnal nasional, tim pengabdian mengadakan kegiatan workshop teknik submission jurnal. Observasi dilakukan melalui pengamatan selama kegiatan berlangsung. Dari kegiatan ini dapat kita lihat antusiasme para peserta dalam mengikuti kegiatan, yaitu dengan membawa perangkat komputer secara lengkap, mulai dari laptop, mouse, hingga wifi portable untuk antisipasi jika jaringan wifi di sekolah terganggu.

Kondisi pelaksanaan pelatihan teknik submission artikel dapat dilihat pada gambar 2 berikut ini.

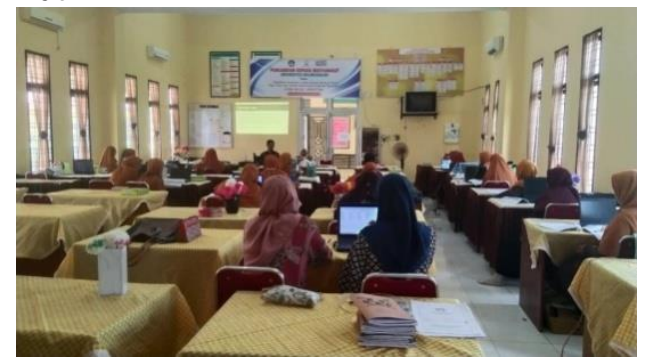

Gambar 2. Peserta mengikuti pelatihan teknik submission pada jurnal nasional

(Sumber: Tim Pengabdian)

Pada kegiatan workshop ini pemateri menyampaikan beberapa syarat wajib yang harus dipenuhi sebelum mensubmit jurnal dan menjelaskan langkah demi langkah untuk mensubmit jurnal ke dalam jurnal nasional. Sebagai contoh pengerjaan submit jurnal, pemateri membuat laman jurnal khusus yang diperuntukkan bagi para peserta pelatihan. Dari laman jurnal tersebut pemateri menyampaikan tahap-tahap submit yang sebenarnya, dan para peserta mengikuti arahan yang pemateri sampaikan mulai dari mengakses website, register akun, sampai akhirnya mengupload karya tulis ke laman jurnal tersebut.

Pada akhir kegiatan workshop ini pemateri mengumumkan para peserta yang berhasil mensubmit karya tulisnya ke dalam laman jurnal yang telah disediakan tersebut. Dari 20 peserta yang mengikuti pelatihan ada sebanyak 8 peserta workshop yang berhasil mengunggah (upload) karya tulisnya ke dalam laman jurnal. Selebihnya ada beberapa peserta yang terkendala pada masalah jaringan internet dan juga dipengaruhi oleh faktor usia yang mengalami masalah dalam kemampuan pengoperasian perangkat laptop dan internet.

Selain itu, di tahap pelatihan teknik submission para peserta juga semangat dalam mengikuti tiap langkah yang dipaparkan oleh pemateri, jika peserta menghadapi kendala dalam mengakses tiap langkah yang diberikan peserta diberikan kesempatan untuk 
memanggil tim pengabdian agar dibantu secara langsung. Tim pengabdi juga mengarahkan secara langsung guru - guru yang sedang melakukan pelatihan, kondisi arahan langsung tim dapat dilihat pada gambar 3 berikut.

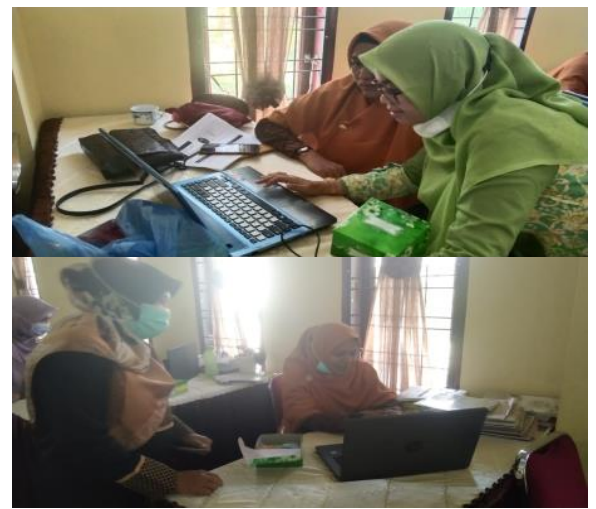

Gambar 3. Tim pengabdian membimbing secara langsung peserta pelatihan

(Sumber: Tim Pengabdian)

\section{Pembahasan}

Kepuasan mitra dalam kegiatan pengabdian masyarakat ini sangat tinggi. Hal ini terlihat dari kuisioner yang dibagikan kepada peserta setelah pemberian materi telah selesai dilaksanakan. Kuisioner yang berupa pertanyaan - pertanyaan yang mengukur tingkat kepuasan mitra terhadap kegiatan ini. Tingkat kepuasan peserta dapat dilihat pada gambar 4 berikut ini.

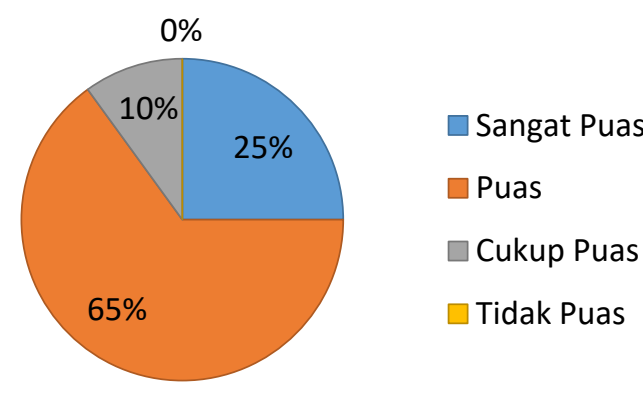

Gambar 4. Persentase kepuasan peserta PKM

Selesainya pelaksanaan kegiatan PKM ini para peserta juga berpesan untuk lebih sering melaksanakan kegiatan pelatihan terkait penulisan artikel ataupun langkah - langkah submission jurnal berbasis OJS.

\section{SIMPULAN DAN SARAN}

Berdasarkan hasil dari kegiatan pengabdian masyarakat yang dilaksanakan oleh tim dosen Universitas Malikussaleh pada tanggal 5 Agustus 2021 di Sekolah SMPN 1 Dewantara, dengan berbagai rangkaian kegiatannya yaitu cara penulisan artikel ilmiah berbasis riset dan teknik submission. Kegiatan ini berjalan dengan lancar dalam memberikan informasi kepada guru tentang cara penulisan dan teknik submission, serta bisa dijadikan sebagai sarana komunikasi yang efektif antara sekolah dan kampus dalam menjalin kerjasama. Peserta sangat antusias dengan kegiatan ini mengingat selama ini belum pernah ada yang melakukan sosialisasi pelatihan cara penulisan artikel dan teknik submissiondisekolahtersebut. Dengan adanya kegiatan ini para guru menyatakan bahwa mereka menjadi lebih pahan dalam menulis karya ilmiah yang selama ini mereka takutkan dan sesuatu yang asing bagi mereka. Banyak manfaat yang merekadapatkan, sehingga nantinya dapat diaplikasikan oleh guru dalam mempublikasi jurnalnya.

Berdasarkan hasil kegiatan PKM ini, maka tim menyarankan bagi para guru disekolah diharapkan yang belum berpengalaman dalam menulis artikel ilmiah, dan teknik submission dapat mengembangkan pengetahuan dan meningkatkan kualitas penulisan artikel ilmiah teknik submission. Selain itu di harapkan dapat menulis karya ilmiah dengan benar dan bisa mensubmit sendiri kejurrnal yang di inginkan.

\section{UCAPAN TERIMAKASIH}

Ucapan terimakasih disampaikan kepada LPPM Universitas Malikussaleh untuk memberikan perizinan melaksanakan kegiatan PKM ini dan kepada SMPN 1 Dewantara yang telah bersedia menjadi mitra dan menyediakan tempat pelaksanaan kegiatan PKM ini

\section{DAFTAR RUJUKAN}

Hamidsyukrie, Z. M., Syafruddin, \& Muntari. (2020). Pendampingan Penyusunan Karya Tulis IImiah Bagi Guru-Guru SMA/MA di Kecamatan Narmada Lombok Barat. Jurnal Pengabdian Magister Pendidikan IPA , 1371-141.

Keputusan Menteri Negara Pendayagunaan Aparatur Negara nomor 84/1993 tentang Jabatan Fungsional Guru dan Angka Kreditnya.

Keputusan bersama Menteri Pendidikan dan kebudayaan dan Kepala BAKN Nomor 0433/P/1993,nomor 25 tahun 1993 tentang Petunjuk Pelaksanaan Jabatan Fungsional Guru dan AngkaKreditnya.

Novita, N., Marhami, Sakdiah, H., \& Muliani. (2021). Pengembangan Kompetensi Literasi Digital Pada Guru Untuk Optimalisasi Pembelajaran Jarak Jauh (PJJ). Matappa: Jurnal Pengabdian Kepada Masyarakat , 51-58.

Sakdiah, H. (2021). ANALISIS MINAT GURU IPA TINGKAT SMP DALAM MENULIS 
PENELITIAN TINDAKAN KELAS

e-ISSN : 2614-526X

(PTK). JURNAL EDUSCIENCE , 70-78 